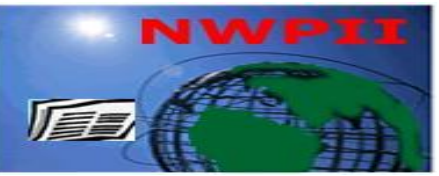

American Journal of Biomedical Sciences

ISSN: 1937-9080

nwpii.com/ajbms

\title{
Epstein-Barr Virus Associated Infectious Diseases in Children
}

\author{
Liwei Gao, Zhengde Xie*, Kunling Shen*
}

Key Laboratory of Major Diseases in Children and National Key Discipline of Pediatrics by Ministry of Education, Beijing Pediatric Research Institute, Beijing Children's Hospital, Capital Medical University, Beijing, PR China

*Corresponding author:

Kunling Shen, Zhengde Xie

Key Laboratory of Major Diseases in Children and National Key Discipline of Pediatrics by Ministry of Education

Beijing Pediatric Research Institute

Beijing Children's Hospital

Capital Medical University

Beijing 100045, PR China

Tel: 13522167212

Email: kunlingshen1717@163.com or xiezhengde@bch.com.cn (Zhengde Xie) or

liwei.gao@ncich.com.cn (Liwei Gao)

Received: 8 October 2014; | Revised: 15 November 2014; | Accepted: 14 December 2014

\begin{abstract}
Epstein-Barr virus (EBV) is a member of the human herpes family and was discovered in cultured cells of Burkitt lymphoma as the first human tumor virus. It has been found to be associated with numbers of tumors, including Hodgkin lymphoma, nasopharyngeal carcinoma, and gastric carcinoma and so on. Besides tumors, EBV also can cause infectious diseases. Infectious mononucleosis, chronic active EBV infection, EBV associated hemophagocytic lymphohistiocytosis are three most common and important EBV associated infectious diseases in children. Infectious mononucleosis is a self limited disease, but the other two diseases are severe diseases with poor prognosis. This review mainly focuses on these three EBV associated infectious diseases in children.
\end{abstract}

Keywords: Epstein-Barr virus, infectious mononucleosis, chronic active EBV infection, EBV-associated hemophagocytic lymphohistiocytosis.

\section{Introduction of Epstein-Barr virus}

Epstein-Barr virus (EBV) is a gamma herpes virus with a double-stranded DNA genome of about $172 \mathrm{~kb}$. Over $95 \%$ of people are infected by this virus. In developed countries, there are two peak ages, between 1 and 5 years of age and the second decade ${ }^{[1]}$. But a study in 1994 revealed that the seroprevalence of EBV in China rose 
rapidly from 1 to 6 years, reaching $80 \%$ by 6 years old, and nearly $100 \%$ by 10 years old ${ }^{[2]}$. Study showed that the seroprevalence of EBV is associated with the economic and sanitary status in one country. With the economic and sanitary conditions improved, EBV infection in early childhood has become less common. For example, the seroprevalence dropped from over $80 \%$ in 1990 to $59 \%$ from 1995 to $1999^{[3]}$ among children age between 5 and 9 years in Japan.

The EBV genome encodes nearly 100 viral proteins ${ }^{[1]}$. These proteins play lots of role in replicating EBV DNA, regulating the expression of EBV genes and human immune response and so on. EBV can cause lytic and latent infection. In lytic infection, EBV fist infect epithelial cells and partly in plasma cells, and encodes lots of viral proteins. In latent infection, EBV genome is located in the nucleus of host lymphocytes, and only 10 viral proteins are expressed, including two types of non-translated RNA, six nuclear protein and two membrane proteins, which can make the virus escape the immune response ${ }^{[1]}$. But latent EBV can be reactivated again.

EBV usually can be transmitted by saliva, rarely by sex. First, it can infect epithelial cells and $\mathrm{B}$ cells. The majority of patients in infants with primary infections are usually asymptomatic; more than $50 \%$ of older children and young adults can develop infectious mononucleosis (IM). IM is a benign and self-limited disease. But in some patients if the host-virus balance is disturbed, these patients have high EBV-DNA load in the peripheral blood and clonal expansion of EBV infected $\mathrm{T}$ cells or natural killer (NK) cells which can lead to chronic active EpsteinBarr virus infection (CAEBV) and EBVassociated hemophagocytic lymphohistiocytosis (EBV-HLH).

\section{Infectious mononucleosis}

Primary EBV infection is usually asymptomatic in most infants and children, but can lead to infectious mononucleosis (IM) in adolescents and adults. IM is a clinical syndrome caused by primary EBV infection which manifest with the triad of fever, lymphadenopathy and pharyngitis, and also with other symptoms such as splenomegaly, palatal petechiae, hepatomegaly and so on. In the United States, the peak age is between 15 and 24 years old ${ }^{[4]}$. But in China, the peak incidence occurred at age of 4 to 6 years ${ }^{[5]}$. These differences may be related to lifestyle, population density, and levels of hygiene. There is no season or sex predilection.

In primary EBV infection, EBV first infect epithelial cells of tonsillar or/and B lymphocytes, and results in viral reproduction with high levels of salivary shedding, which decrease over the first year of infection but persist for life. The typical manifestation of IM is due to the transient proliferation of EBV-infected $B$ cells accompanied by excessive response of EBVspecific cytotoxic $T$ cells (CTL) ${ }^{[6]}$. The latter cells can release lots of cytokines and impair the function of the organs which may contribute to the symptoms of IM. But on the other hand, these cellular immune responses are helpful to control EBV infection.

The incubation period was about 30 to 50 days ${ }^{[4]}$. IM is recognized as the typical clinical syndrome of primary EBV infection, which presents with the triad of fever, pharyngitis, cervical adenopathy, and other various manifestations such as hepatomegaly, splenomegaly, rash, puffy eyelid. A study from China reported that $75.6 \%$ of the patients with EBV-IM presented with fever, lymphadenopathy, and pharyngitis ${ }^{[5]}$. And it also suggest that the incidences of hepatomegaly, splenomegaly and rash were higher in the infantile group than in the older groups, but tonsillopharyngitis and liver function impairments are more common in older children. The differences of clinical manifestation in different age groups may be correlated to the degree of maturity of the immune system in children. Williams also indicated that the variability in clinical features of IM directly related to the level of $\mathrm{T}$ cell activation, which, in turn, related to the number of EBV-infected $\mathrm{B}$ cells in the circulation ${ }^{[7]}$.

The appearance of atypical lymphocytes $(>10 \%)$ in peripheral blood is another feature of IM. The sensitivity and specificity for the diagnosis of IM in older children and young adult respectively $75 \%$ and $92 \%{ }^{[8]}$, but in younger children the rate of atypical lymphocytosis 
(>10\%) was lower, only 41.8-51.9\% ${ }^{[5,9]}$. Primary EBV infection also can induces the activity of a heterogeneous group of circulating heterophile (IgM) antibodies directed against viral antigens that cross-react with antigens found on sheep and horse red cells. The positive rate of heterophile antibody has $85 \%$ sensitivity and $94 \%$ specificity for the diagnosis of IM in young adult. But in children of less than 12 years of age, the positive rate is only 25 to $50 \%{ }^{[10]}$. The definitive diagnosis of EBV infection can be made by testing for specific IgM and IgG antibodies against viral capsid antigens (VCA), early antigens (EA), and EBV nuclear antigen (NA) proteins ${ }^{[11]}$. VCA-IgM appears early and exists for 4 to 8 weeks. But in some children, VCA-IgM appears delayed or never is detected ${ }^{[12]}$. In later time of acute infection, EA-IgG can be detected; it can last for several months or years. NA-IgG will be not detectable until six to eight weeks after the onset of symptom. NA-IgG and VCAIgG will exist for all the human life. In recent years, low avidity antibody of VCA-IgG was used to diagnose acute EBV infection, the positive rate can reach to $90 \%$ in 10 days and 30 days later also can reach $50 \%$. Combined with negative NA-IgG and low avidity antibody of VCA-IgG, the sensitivity and specificity for the diagnosis IM can reach $100 \%{ }^{[13]}$. Higher EBVDNA load without serological results of antibodies can not certify primary EBV infection, but mornitoring EBV-DNA load may be useful for assessing the severity of the disease. EBVDNA load of PBMC in patients with IM is usually $\left(10^{2} \sim 10^{3}\right) \times 10^{6}$ copies/ $\mu \mathrm{g}^{-} \mathrm{DNA}$, but in patients with EBV-HLH, it can reach $\left(10^{3} \sim 10^{6}\right)$ $\times 10^{6}$ copies/ $\mu \mathrm{g}$ DNA which is higher than IM. So it is necessary to pay more attention to the patients of IM with higher EBV-DNA load, because they may be more likely to progress to EBV-HLH ${ }^{[14]}$.

The clinical and laboratory characteristics of IM in children may be varied with ages and countries. The initial diagnostic criteria was put forward by Hoagland in $1975^{[15]}$, including the presence of fever, pharyngitis, and adenopathy, at least 50\% lymphocytes and existing atypical lymphocytes $(>10 \%)$, and heterophile antibody. The standard is suitable for IM patients in
Western countries because the peak age is between 10 and 30 years old. But in China, the peak age of IM is preschool and school-age children, and the serum heterophile antibody often is negative, atypical lymphocyte proportion $(>10 \%)$ in peripheral blood was lower than Western countries, just only 41.8 to $51.9 \%$. So, according to our experimental and clinical experience, the following diagnosis criteria for Chinese patients were suggested ${ }^{[16]}$ : (1) presence of at least three of the following clinical manifestations: fever, tonsillopharyngitis, cervical lymphadenopathy, hepatomegaly or splenomegaly; (2) at least one of the following 4 laboratory findings: CA-IgM and CA-IgG positve and NA-IgG negative; CA-IgM negative but CAIgG positve with low avidity; at least $10 \%$ atypical lymphocytes; a positive heterophile antibody test. If the children meet the above 2 items at the same time, they can be diagnosed with IM. Of course, it need to be distinguished from other diseases with similar symptoms to IM, such as cytomegalovirus, human immunodeficiency virus (HIV), human herpesvirus 6 (HHV-6), or Toxoplasma infection [17].

IM is a self-limited disease. The majority of IM recovers without sequelae and return to normal activities within 2 months after the onset of symptoms, except a few cases with severe complications ${ }^{[9]}$. A previous study on children in the mainland of China revealed that the incidence of complications can reach $80 \%{ }^{[18]}$. Pneumonia was the most common complication, and others such as thrombocytopenia, neutropenia, hematological system problems, spleeny rupture and neurological complications were also been seen. Grotto et al. [19] showed parenchyma damage and thrombocytopenia were more common in older children.

The mainstay of treatment of IM is good supportive care, including adequate liquid, resting in bed, antifebrile drugs for fever and myalgias and so on. Antiviral drugs have been controversial for treating IM patients. At least five randomized, controlled trials of acyclovir treatment for IM have shown a transient reduction in oropharyngeal viral shedding during treatment, but did not significantly reduce 
peripheral-blood EBV levels or the duration or severity of clinical symptoms ${ }^{[20]}$. Recent studies ${ }^{[21,22]}$ comparing valacyclovir with placebo in 20 young adults with IM showed a transient decreasing of oropharynx EBV shedding during therapy and a reduction in the number and severity of reported symptoms in the valacyclovir group, but no difference between these two groups in the peripheral-blood EBV load. Larger randomized, blinded, placebo-controlled trials are necessary to verify these results. Candy et al. ${ }^{\text {[23] }}$ indicated that corticosteroids may be helpful in the management of more severe complications of IM, such as upper-airway obstruction and hemolytic anemia and so on. In China, Cao et al. [24] conducted a controlled trial of traditional Chinese medicine treatment for IM have shown reducing the length of stay.

\section{CAEBV}

In 1988, Straus ${ }^{[25]}$ first defined chronic active EBV (CAEBV) infection which characterized by chronic or recurrent IM like symptoms persisting over a long time and by an unusual pattern of anti-EBV antibodies. The pathogenesis of CAEBV is unclear. Different from IM, EBV infects T cells (non CD8+T cells) or natural killer (NK) cells in patients with CAEBV ${ }^{[26]}$. T and NK cells do not express molecule CD21 which is EBV receptor, so the mechanism of EBV infection is not known. Transfer of CD21 from B cells to NK cells through immunological synapse may render the latter cells accessible to EBV then induce the clonal proliferation of EBV-infected $\mathrm{T}$ cells or NK cells which were laden with EBV DNA ${ }^{[27]}$. The mechanism why EBV induces proliferation of $\mathrm{T}$ cells and NK cells is not known either. EBVinduced expression of CD40 and its engagement by CD40L may play a role in the survival of EBV-infected $T$ and NK cells of CAEBV patients and may explain the reason ${ }^{[28]}$. Then these abnormal activating cells induce cytokine releasing disorderingly, including interleukin (IL)-1 $\beta$, IL-10, and interferon (IFN)- $\gamma$, etc, which levels are much higher than those in patients with IM and are comparable with those of EBVassociated $\mathrm{T}$ cell granular lymphoproliferative disease $^{[29]}$. The high levels of cytokine may be associated with disease progression in CAEBV. Also, some study reported viral interleukin-10 (IL-10) can be detected that is a product of the Epstein-Barr virus (EBV) replication gene BCRF1 ${ }^{[30]}$. Its function is similar to the human cytokine IL-10 which could inhibit $\mathrm{T}$ cell immunity and IFN- $\gamma$ production and promote the proliferation of EBV-infected cells, then could help EBV survive and spread in its host. But one study demonstrated that the activated $T$ cells and NK cells of CAEBV were lack of cytotoxicity of EBV specific killing activity. Katano et al. [31] found that patients with CAEBV have mutations in the gene encoding perforin, which has a critical role in granule-mediated killing of target cells that influence the killing function of $\mathrm{T}$ cells and NK cells. At the same time, some studies ${ }^{[32]}$ have found that chromosome aberration exist in peripheral blood cells of $50 \%$ patients with CAEBV. Then karyotype analysis indicates that patients with abnormal karyotype imply that the diseases have a malignant nature.

CAEBV is more frequently found in Asian countries, such as China and Japan, and mainly occurs in children and adolescents. The clinical manifestations are diversity. IM-like symptoms are the main symptoms of CAEBV ${ }^{[33]}$. Other clinical manifestations include anemia, thrombocytopenia, pancytopenia, diarrhea, and uveitis, etc. Depending on which lymphocyte subset is mainly infected by EBV, CAEBV were classified into three clinical types ${ }^{[26]}$, T-cell, NKcell and B-cell types. T cell type of CAEBV is mainly manifested as fever and high titers of EBV related antibody; the main mechanism is the activation of $\mathrm{T}$ cell and cytokine releasing which will lead to severe inflammation and fever. NK cell type of CAEBV mainly characterized by allergy to mosquito and corresponding skin damage, increased numbers of large particles of abnormal lymphocytosis and elevated IgE titer. T-cell type is more common and have poor prognosis than NK-cell type, but the abnormal chromosome in NK cell type is more common than T cell type. All of the two types are likely to develop abnormal proliferation of $\mathrm{T} / \mathrm{NK}$ cells associated lymphatic disease, even can cause 
malignant lymphoma or NK cell leukemia. B-cell type of CAEBV is rare.

In 2005, Okano et al. ${ }^{[34]}$ proposed the diagnostic guideline of CAEBV. All the patients should satisfy the followings: (1) Persistent or recurrent IM-like symptom; (2) Raised antiEBV-VCA and anti- EBV-EA antibodies, and/or detecting the increased EBV genomes in peripheral blood or other affected tissues; (3) Chronic illness that cannot be explained by other known disease. Peripheral blood EBV-DNA load usually exceeds $10^{2.5}$ copies/ $\mu$ g DNA. The amount of viral DNA seems to be a prognostic marker for CAEBV. Recently, a study from Japan [35] supposed that EBV-encoded microRNA (miRNA) may be a potential biomarker of CAEBV. MiRNA is a small non-coding RNA that has 18-25 nucleotides. It plays a critical role in the regulation of cell differentiation and proliferation by regulating mRNA translation. EBV is the first virus to encode miRNAs. Kawano et al. reported that plasma levels of miRBART 2-5p, 1-5p, 5, and 22 are significantly higher in patients with CAEBV than in patients with IM and healthy controls. Plasma miR-BART $2-5 p, 4,7,13,15$, and 22 levels were significantly elevated in CAEBV patients with active disease compared to those with inactive disease. Similarly, plasma miR-BART 2-5p and 15 levels could clearly differentiate patients with complete remission from others. So, miRBART2-5p, 13, and 15, are potentially biomarkers of disease severity or prognosis. Importantly, plasma EBV DNA level did not show any significant correlation with these clinical parameters. These results suggest that EBV-encoded miRNA in plasma may be a useful biomarker for the diagnosis and monitoring of CAEBV.

Now, the patients of CAEBV are still lack of standardized and effective treatment, even though various therapies have been tried which including antiviral, chemotherapeutic, and immunomodulatory drugs $[36,37]$. Conventional antiviral therapy can decrease viral load of EBV, but the effect is transient. Immunomodulatory drugs, such as human immunoglobulin, had been proved effective for EBV-HLH. When some cases combined with HLH, chemotherapy drugs such as etoposide (VP-16), hormone, and cyclosporine can be used. In recent years, infusion of autologous EBV specific CTL cells has achieved success ${ }^{[38]}$. This treatment can awaken the immune response of specific EBV cell in immunodeficient patients, and improve the symptoms of patients with CAEBV. Savoldo et al. ${ }^{[39]}$ reported that after infusion EBV specific CTL, 5 patients stopped fever and lymphadenectasis returned to normal, serum EBV antibody levels dropped, of which 4 cases were without recurrence after follow-up for 36 months, only 1 case was recurrent after 1 year. But the effect in severe CAEBV cases have also not be confirmed. The above treatment induced sustained complete remission in only exceptional cases and haemopoietic stem cell transplant (HSCT) is at present the only curative therapy for CAEBV ${ }^{[40]}$. Jeffery et al. ${ }^{[41]}$ conducted a retrospective summary of the American patients with CAEBV lasting for 28 years, among 8 patients received the treatment of HSCT, 5 cases $(63 \%)$ were longterm survival and 3 cases were progression to EBV associated lymphoma and died. In Japan and New Zealand's study ${ }^{[42]}, 41$ cases among 57 cases with CAEBV treated by allo-HSCT survived. Kawa et al. ${ }^{[43]}$ reported excellent results of HSCT that the 3 years overall survival rate was $95.0 \pm 4.9 \%$. HSCT is thus the therapy of choice for CAEBV, but it is still accompanied by substantial risk and CAEBV patients have high risk for transplantation-related complications. Gotoh et al. ${ }^{[44]}$ summarized 15 patients who received the treatment of HSCT, and found that 7 cases were dead after transplantation and 3 cases died of recurrence.

In addition, Iwata et al. ${ }^{[45]}$ investigated the effect of bortezomib on EBV infected T-cell lines including those derived from CAEBV and found that bortezomib induced the expression of EBV lytic-cycle genes BZLF1 and gp350/220, as has been reported for EBV infected B-cell lines and also induced apoptosis specifically in EBVinfected $\mathrm{T}$ or $\mathrm{NK}$ cells cultured ex vivo from patients with EBV+T/NK-LPD. Iwata et al. ${ }^{[46]}$ also examined the effect of valproic acid on EBV-infected $\mathrm{T}$ and $\mathrm{NK}$ cell lines and found that this agent also can induces apoptosis in human EBV-infected $\mathrm{T}$ and NK cells. 
Overall, the prognosis of patients with CAEBV is not good, especially with severe complications. When the first symptom of CAEBV occurred, half of the patients will die in 5 years later because of severe complications which including liver function failure, heart failure, and various types of abnormal proliferation of lymphatic diseases, opportunistic infections and HLH. A study ${ }^{[33]}$ conducted by Beijing Children's Hospital had reported that 26.2\% patients with CAEBV died in 7 months to 3 years after onset. Deceased patients were more likely to have had lower platelet counts and albumin levels than the living patients. So thrombocytopenia and decreases in albumin might potentially be risk factors for a poor prognosis.

\section{EBV-HLH}

Although primary EBV infection is rarely fatal, fulminant infection may occur, such as Epstein-Barr virus associated hemophagocytic lymphohistiocytosis (EBV-HLH). EBV-HLH is the most important types of secondary HLH and manifest with prolonged fever, hepatosplenomegaly, rash, and lymphadenopathy and so on [47, 48]. A nationwide survey [49] conducted in Japan showed that one HLH case in 800,000 persons can occurs and half of cases were associated with EBV infection. EBV-HLH can be caused by primary EBV infection or reactivation of previous $\mathrm{EBV}$ infection, but the latter is more common. Imashuku ${ }^{[50]}$ reported 94 cases with EBV-HLH and found that $66 \%$ of the patients were previous EBV infection with negative VCA-IgM. It is known that the disease occurs commonly in children and adolescents living in Asian countries. Epidemiological data of Japan ${ }^{[50]}$ shows that there are 25 cases of EBVHLH each year in Japan. China's population is 10 times more than Japan, because Chinese and Japanese belong to the yellow race, according to conservative estimates of the same incidence, so there may be at least 250 to 300 cases of EBVHLH in China every year.

EBV-HLH is more severe than other secondary HLH and have poor prognosis. This life-threatening condition is a type of immune dysregulation characterized by an impaired or absent function of natural killer (NK) cells and $\mathrm{T}$ cells (mainly CD8+T cells), and the release of proinflammatory cytokines which can cause injury of multiple organs and tissues ${ }^{[51]}$. Qin et al. ${ }^{[52]}$ conducted a study to detect the expression of NK cell surface receptors and CD107a in EBVHLH children in china. They found that the expression of CD107a、CD107a/NKG2D of NK cells in patients with EBV-HLH have no change after stimulated by IL-2 which is not consistent with healthy control group. In addition, genetic defects in cellular cytotoxicity pathways and aberrant regulation of inflammatory responses have been identified in some infants and children with EBV-HLH, including PRF1、SH2D1A 、 UNC13D and STX11 etc ${ }^{[53]}$. Recently, in order to confirm whether patients presented with EBVHLH harbor the potential gene mutations of familial hemophagocytic lymphohistiocytosis (FHL) or X-linked lymphoproliferative syndrome (XLP) in Chinese children, Huang et al. [54] investigated the PRF1, UNC13D, STX11, SH2D1A, XIAP, and ITK gene mutations in 67 Chinese patients with EBV-HLH. They found one-tenth of the patients with EBV-HLH have genetic defects of primary HLH, including five missense mutations in PRF1 (five patients), four mutations in UNC13D (two patients) and one mutation in XIAP (one patient). No gene mutations of PRF1/UNC13D/STX11/SH2D1A/XIAP/ITK

were found in the majority of Chinese child patients with EBV-HLH. Most patients with EBV-HLH have no known genetic defects of FHL and XLP. If the patients with EBV-HLH were confirmed to have related gene mutation, they should be diagnosed as FHL or XLP.

EBV-HLH was observed in infants, children, and adults, but $80 \%$ of the cases occurred in children 1 to 14 years of age. Patients with HLH have a wide clinical spectrum but typically present with high fever, hepatosplenomegaly, cytopenias, coagulation abnormalities, and tissue evidence of hemophagocytosis. Coagulopathy, pleural effusion, ascites and CNS disease can also occur. EBV-DNA load in patients with EBVHLH is higher than patients with IM and it is related to the severity of the disease. Currently, 
there are no diagnostic criteria of EBV-HLH. Diagnosis of EBV-HLH includes two aspects, one is meeting the diagnosis of HLH and the other is having an evidence of EBV infection. Diagnostic criteria for HLH disease were expanded in $2004^{[55]}$. Five of following eight criteria are required to fulfill a clinical diagnosis of HLH, including: 1. Fever; 2. Splenomegaly; 3. Cytopenia (affecting $\geq 2$ of 3 lineages in the peripheral blood: Hemoglobin $<90 \mathrm{~g} / \mathrm{L}$ (in infants $<4$ weeks: hemoglobin $<100$ g/L); Platelets $<100 \times 10^{9} / \mathrm{L}$; Neutrophils $\left.<1.0 \times 10^{9} / \mathrm{L}\right) ; 4$. Hyper Triglyceridemia $\quad(\geq 3.0 \quad \mathrm{mmol} / \mathrm{L}) \quad$ or Hypofibrinogenemia $\quad(\leq 1.5 \mathrm{~g} / 1) ; \quad 5$. Hemophagocytosis in bone marrow or spleen or lymph nodes and no evidence of malignancy; 6 . Low or absent NK cell activity (according to local laboratory reference); 7. Serum ferritin level $\geq 500 \mu \mathrm{g} / \mathrm{L} ;$ 8. Soluble CD25 (soluble IL-2 receptor) level at $\geq 2400 \mathrm{U} / \mathrm{ml}$. Diagnostic criteria for EBV infection including the following one or more: 1) primary EBV infection with VCA-IgM (+) and (or) EBV-EA-IgG (+), EBV-NA-IgG(-); if VCA-IgM(-) but with low avidity VCA-IgG; 2 ) if VCA-IgG (+) and (or) EA-IgG (+) and NA$\mathrm{IgG}(+)$ indicate $\mathrm{EBV}$ reactivity; 3) Increased plasma EBV-DNA load or EBV-encoded small RNA (EBER) positive cells were detected in involved tissues. Because of similar clinical characteristics, EBV-HLH is difficult to differentiate from FHL. In addition, some FHL are triggered by EBV infection. Genetic detection is helpful to differentiate EBV-HLH from FHL.

EBV-HLH is a relatively rare and lifethreatening disease in children. Even after aggressive therapy, the overall fatality rate of EBV-HLH is $56.7 \%{ }^{[56]}$. The aim of therapy is to control the cytokine storm generated by EBV infection and to suppress clonally proliferating EBV-genome-containing cells. Conventional antiviral therapy is usually not useful. Treatment options include proapoptotic chemotherapy or more targeted immunotherapy approach. Since using the protocol of HLH-2004 in the clinical, the prognosis of EBV-HLH had been more greatly improved than before using HLH-1994 protocol. The protocol is divided into two stages: initial treatment and consolidation treatment, which drugs including etoposide, dexamethasone, methotrexate and cyclosporine A, etc. The total time of treatment was 40 weeks. Early chemotherapy can reduce the mortality and improve the prognosis. But, currently, the longterm efficacy of HLH-2004 protocol for EBVHLH is not satisfactory. There is still a high rate of recurrence. A study ${ }^{[57]}$ reporting 17 patients with EBV-HLH treated by HLH-2004 protocol, 5 cases occurred severe adverse reaction of central nervous system and 4 cases twitched with obvious abnormal performance on MRI and 1 case was died of intracranial hemorrhage. Hypertension and the function of liver and kidney damaging, elevated CSA concentration over the range of treatment concentration were the causes of adverse reactions of central nervous system. In addition, there were still other treatments for EBV-HLH. Anti-thymocyte globulin (ATG) has some therapeutic potential by virtue of its anticytokine effect. Intravenous immunoglobulin (IVIG) treatment as also been used but is now believed to be of limited effect. If the patients with FHL, XLP and chronic active EBV infection of EBV-HLH, and refractory EBV-HLH, they needs haemopoietic stem cell transplant (HSCT). Use of HSCT with both matched related and matched unrelated donors in the context of HLH94 improved 3-year survival to $55 \%$ for all cases and $51 \%$ for confirmed familial cases ${ }^{[58]}$.

Recently, in Japan, Ohga et al. [59] summarized the treatment of HSCT for 57 cases, including FHL (43 cases) and EBV-HLH (14 cases), and found that the overall survival rates of 10 years of FHL and EBV-HLH were $65.0 \% \pm 7.9 \%$ and $85.7 \% \pm 9.4 \%$ respectively. Umbilical cord blood transplantation was also an effective method for treatment of HLH. These studies showed that the survival rate was more than $65 \%$. Regarding the HSCT results, some studies have found patients with refractory $\mathrm{T}$ cellproliferating EBV-HLH tend to have a better outcome than refractory NK-cell proliferating EBV-HLH patients. Despite the utility of HSCT in treating refractory EBV-HLH cases, it should be emphasized that even successfully engrafted cases can succumb to transplant-related complications. A study ${ }^{[60]}$ of 26 patients received HSCT, 19 patients are alive in complete remission and the remaining 7 died consequent to 
transplant-related complications or progressive CNS disease. Thus EBV-HLH recipients of HSCT should be carefully monitored for the development of various complications, especially for post-transplant hemophagocytic syndrome.

EBV-HLH has a high rate of morbidity and fatality, especially for the patients with immunodeficiency. If not conducting HSCT, the survival rate of 3 month was only $51 \%{ }^{[58]}$. To improve the outcome of patients with EBV-HLH, intensive supportive care during the initial treatment that prevents the fatal complications of this disease must be instituted. Previous study ${ }^{[58]}$ have reported that younger age, neutropenia, PLT $<20 \times 10^{9} / \mathrm{L}$, increased lactate dehydrogenase (LDH) and ferritin, decreased fibrinogen and NK cell activity were risk factors of death of patients with EBV-HLH, so it is necessary for doctor to monitoring these factors which may contribute to reduce the fatality of EBV-HLH. In addition, because part of the EBV-HLH having genetic defect of PRFl, UNCi3D, SH2DIA etc, especially the infants, EBV-HLH should be distinguished from FHL.

\section{Conclusion}

IM is a benign and self-limited disease, but CAEBV and EBV-HLH are severe EBVassociated diseases with poor prognosis. The comparison of these three EBV associated infectious diseases shows in table 1. The pathogenesis of CAEBV and EBV-HLH is unclear. Parts of CAEBV and EBV-HLH have genetic mutation. More studies are needed to focus on the pathogenesis of CAEBV and EBV$\mathrm{HLH}$, and new therapy for CAEBV and EBVHLH is also needed to explore in the future.

Table 1 Comparison of the three EBV associated infectious diseases

\begin{tabular}{|c|c|c|c|}
\hline & IM & CAEBV & EBV-HLH \\
\hline Epidemiology & $\begin{array}{l}500 \text { in } 100,000 \text { persons } \\
\text { per year }^{[4]}\end{array}$ & $\begin{array}{l}\text { Rarely, but more in Asian } \\
\text { countries }\end{array}$ & $\begin{array}{l}1 \text { in } 800,000 \text { persons per } \\
\text { year }^{[49]}\end{array}$ \\
\hline Pathogenesis & $\begin{array}{l}\text { EBV infects B cells and } \\
\text { then leads to the } \\
\text { proliferation of CTL } \\
\text { cells and NK cells }\end{array}$ & $\begin{array}{l}\text { Not well clear, Proliferation } \\
\text { of NK cells and/or T cells } \\
\text { infected by EBV(mainly } \\
\text { CD4+T cells) }\end{array}$ & $\begin{array}{l}\text { Not well clear, Cytokine } \\
\text { storm induced by EBV } \\
\text { infecting NK cells and T } \\
\text { cells (mainly CD8+T } \\
\text { cells) }\end{array}$ \\
\hline Etiology & EBV infection & $\begin{array}{l}\text { EBV infection, Part with } \\
\text { genetic mutation }\end{array}$ & $\begin{array}{l}\text { EBV infection, Part with } \\
\text { genetic mutation }\end{array}$ \\
\hline Diagnosis criteria & $\begin{array}{l}\text { Referred by Hoagland } \\
\text { RJ. }{ }^{[15]}\end{array}$ & $\begin{array}{l}\text { Referred by Okano M, et } \\
\text { al. }^{[34]}\end{array}$ & $\begin{array}{l}\text { Referred by Henter J.I, et } \\
\text { al. }^{[55]}\end{array}$ \\
\hline Treatment & $\begin{array}{l}\text { Symptomatic and } \\
\text { supportive }\end{array}$ & $\begin{array}{l}\text { HSCT is the only curative } \\
\text { therapy }\end{array}$ & Chemotherapy and HSCT \\
\hline Prognosis & $\begin{array}{l}\text { Benign and self- } \\
\text { limited, More than } 95 \% \\
\text { are good }^{[4]}\end{array}$ & $\begin{array}{l}\text { Poor, and fatality rate is } \\
\text { about } 26.2 \%\end{array}$ & $\begin{array}{l}\text { Poor, and fatality rate is } \\
\text { over } 50 \%\end{array}$ \\
\hline
\end{tabular}




\section{References}

1. Cohen J.I. Epstein-Barr virus infection, N Engl J Med, 2000, 343(7), 481-492. DOI: 10.1056/NEJM200008173430707

2. Kangro H.O.; Osman H.K.; Lau Y.L.; Heath R.B.; Yeung C.Y.; Ng M.H. Seroprevalence of antibodies to human herpesviruses in England and Hong Kong, J Med Virol, 1994, 43(1),91-96. DOI: 10.1002/jmv.1890430117

3. Takeuchi K.; Tanaka-Taya K.; Kazuyama Y.; Ito Y.M.; Hashimoto S.; Fukayama M.; Mori S. Prevalence of Epstein-Barr virus in Japan, trends and future prediction, Pathol Int, 2006, 56(2),112-116. DOI: 10.1111/j.14401827.2006.01936.x

4. Luzuriaga K, Sullivan J L, John L. Sullivan. Infectious mononucleosis, $\mathrm{N}$ Engl J Med, 2010, 362(21), 1993-2000. DOI: 10.1056/NEJMcp1001116

5. Li-Wei G.; Zheng-De X.; Ya-Yi L.; Yan W.; Kun-Ling S. Epidemiologic and clinical characteristics of infectious mononucleosis associated with Epstein-Barr virus infection in children in Beijing, China, World $\mathrm{J}$ Pediatr, 2011, 7(1), 45-49._DOI: 10.1007/s12519-011-0244-1

6. Thorley-Lawson D.A. Epstein-Barr virus: exploiting the immune system, Nat Rev Immunol, 2001, 1(2),75-82. DOI: $10.1038 / 35095584$

7. Williams H.; Macsween K.; McAulay K.; Higgins C.; Harrison N.; Swerdlow A.; Britton K.; Crawford D. Analysis of immune activation and clinical events in acute infectious mononucleosis, J Infect Dis, 2004, 190(1),63-71. DOI: 10.1086/421276

8. Ebel MH. Epstein-Barr virus infectious mononucleosis, Am Fam Physician, 2004, 70(7), 1279-1287.

9. Tsai M.H.; Hsu C.Y.; Yen M.H.; Yan D.C.; Chiu C.H.; Huang Y.C.; Lin S.J.; Lin T.Y. Epstein-Barr virus-associated infectious mononucleosis and risk factor analysis for complications in hospitalized children, $\mathbf{J}$ Microbiol Immunol Infect, 2005, 38(4),255261.

10. Papesch M.; Watkins R. Epstein-Barr virus infectious mononucleosis, Clinical Otolaryngology \& Allied Sciences, 2008, 26(1),3-8. $\quad$ DOI: $10.1046 / j .1365-$ 2273.2001.00431.x

11. Cohen JI. Clinical aspects of Epstein-Barr virus infection, Caister Academic Press, 2005, 80(4), 35-54.

12. Gulley M.L.; Tang W. Laboratory assays for Epstein-Barr virus-related disease, JMD, 2008, 10(4), 279-292. DOI: 10.2353/jmoldx.2008.080023

13. Robertson P.; Beynon S.; Whybin R.; Brennan C.; Vollmer-Conna U.; Hickie I.; Lloyd A. Measurement of EBV-IgG antiVCA avidity aids the early and reliable diagnosis of primary EBV infection, J Med Virol, 2003, 70(4),617-623. DOI: 10.1002/jmv.10439

14. Kimura H.; Morita M.; Yabuta Y.; Kuzushima K.; Kato K.; Kojima S.; Matsuyama T.; Morishima T. Quantitative analysis of Epstein-Barr virus load by using a real time PCR assay, J Clin Microbiol, 1999, 37(1),132-136.

15. Hoagland RJ. Infectious mononucleosis, Prim Care, 1975 Jun; 2(2), 295-307.

16. Zhengde $X$. Clinical features and diagnositc criteria of infectious mononucleosis associated with Epstein-Barr virus infection in children, J Appl Clin Pediatr, 2007, 22(22) , 1759-1760.

17. Naito T.; Kudo N.; Inui A.; Matsumoto N.; Takeda N.; Isonuma H.; Dambara T.; Hayashida Y. Causes of Infectious Mononucleosis-like Syndrome in Adult Patients, Internal med, 2006, 2(45),17-25.

18. Jenson H.B. Acute complications of EpsteinBarr virus infectious mononucleosis, Curr Opin Pediatr, 2000, 12(1), 263-268. DOI: 10.1097/00008480-200006000-00016

19. Grotto I.; Mimouni D.; Huerta M.; Mimouni M.; Cohen D.; Robin G.; Pitlik S.; Green M.S. Clinical and laboratory presentation of EBV positive infectious mononucleosis in young adults, Epidemiol Infect, 2003, 131(2),683-689. $10.1017 / \mathrm{S} 0950268803008550$

20. Jenson H.B. Virologic diagnosis, viral monitoring, and treatment of Epstein-Barr 
virus infectious mononucleosis, Curr Infect

Dis Rep, 2004, 6(3),200-207. DOI: 10.1007/s11908-004-0009-2

21. Balfour HH Jr; Hokanson K.M.; Schacherer R.M.; Fietzer C.M.; Schmeling D.O.; Holman C.J.; Vezina H.E.; Brundage R.C. A virologic pilot study of valacyclovir in infectious mononucleosis, J Clin Virol, 2007, 39(1),16-21. DOI: 10.1016/j.jcv.2007.02.002

22. Hoshino Y.; Katano H.; Zou P.; Hohman P.; Marques A.; Tyring S.K.; Follmann D.; Cohen J.I. Long-term administration of valacyclovir reduces the number of EpsteinBarr virus (EBV)-infected B cells but not the number of EBV DNA copies per B cell in healthy volunteers, J Virol, 2009. 83(1), 11857-61. DOI: 10.1128/JVI.01005-09

23. Candy B.; Hotopf M. Steroids for symptom control in infectious mononucleosis, Cochrane Database Syst Rev, 2006. 19(3), CD004402.

24. Cao Z.X.; Zhao Z.F.; Zhao X.F. Effect of compound glycyrrhizin injection on liver function and cellular immunity of children with infectious mononucleosis complicated liver impairment, Chin J Integr Med, 2006, 12(4),268-272. DOI: 10.1007/s11655-006$\underline{0268-1}$

25. Straus S.E. The chronic mononucleosis syndrome, J. Infect Dis, 1988, 157(1), 40512. DOI: $10.1093 /$ infdis/157.3.405

26. Kimura H.; Hoshino Y.; Hara S.; Sugaya N.; Kawada J.; Shibata Y.; Kojima S.; Nagasaka T.; Kuzushima K.; Morishima T. Differences between $\mathrm{T}$ cell type and natural killer celltype chronic active Epstein-Barr virus infection, J Infect Dis,2005, 191(4), 531-539. DOI: $10.1086 / 427239$

27. Tabiasco J.; Vercellone A.; Meggetto F.; Hudrisier D.; Brousset P.; Fournié JJ. Acquisition of viral receptor by NK cells through immunological synapse, J. Immunol, 2003, 170(12), 5993-8. DOI: 10.4049/jimmunol.170.12.5993

28. Imadome K.; Shimizu N.; Arai A.; Miura O.; Watanabe K.; Nakamura H.; Nonoyama S.; Yamamoto K.; Fujiwara S. Coexpression of CD40 and CD40 ligand in Epstein-Barr virus-infected $\mathrm{T}$ and $\mathrm{NK}$ cells and their role in cell survival, J Infect Dis, 2005, 192(8), 1340-48. DOI: 10.1086/466530

29. Kimura H, Hoshino Y, Kane gane H, Tsuge I, Okamura T, Kawa K, Morishima T. Clinical and virologic characteristics of chronic active Epstein-Barr Virus infection, Blood, 2001,98(2) , 280-286. DOI: 10.1182/blood.V98.2.280

30. Kanegane H.; Wakiguchi H.; Kanegane C.; Kurashige T.; Tosato G. Viral Interleukin-10 in Chronic Active Epstein-Barr Virus Infection, J Infect Dis, 1997, 176(1),254257. DOI: $10.1086 / 517260$

31. Katano H.; Ali M.A.; Patera A.C.; Catalfamo M.; Jaffe E.S.; Kimura H.; Dale J.K.; Straus S.E.; Cohen J.I. Chronic active Epstein-Barr virus infection associated with mutations in perforin that impair its maturation, Blood, 2004, 103(3), 1244-52.

32. Hochberg D.; Souza T.; Catalina M.; Sullivan J.L.; Luzuriaga K.; ThorleyLawson D.A. Acute infection with EpsteinBarr virus targets and overwhelms the peripheral memory B-cell compartment with resting latently infected cells, J viroI, 2004, 78(10),5194-5204.

33. Lu G.; Xie Z.D.; Zhao S.Y.; Ye L.J.; Wu R.H.; Liu C.Y.; Yang S.; Jin Y.K.; Shen K.L. Clinical analysis and follow-up study of chronic active Epstein-Barr virus infection in 53 pediatric cases, Chin Med J, 2009,122(3),262-266.

34. Okano M.; Kawa K.; Kimura H.; Yachie A.; Wakiguchi H.; Maeda A.; Imai S.; Ohga S.; Kanegane H.; Tsuchiya S.; Morio T.; Mori M.; Yokota S.; Imashuku S. Proposed guidelines for diagnosing chronic active Epstein-Barr virus infection, Americ $\mathbf{J}$ Hematol, 2005, 80(1),64-69. DOI: 10.1002/ajh.20398

35. Kawano Y.; Iwata S.; Kawada J.; Gotoh K.; Suzuki M.; Torii Y.; Kojima S.; Kimura H.; Ito Y. Plasma viral microRNA profiles reveal potential biomarkers for chronic active Epstein-Barr virus infection, J Infect Dis, 2013, 208(5), 771-9. DOI: 10.1093/infdis/jit222

36. de Boer M.; Mol M.J.; Bogman M.J.; Galama J.M.; Raymakers R.A. Chronic 
active Epstein-Barr virus infection in an adult with no detectable immune deficiency, Neth J Med, 2003, 61(11),376-382.

37. Iwata S.; Wada K.; Tobita S.; Gotoh K.; Ito Y.; Demachi-Okamura A.; Shimizu N.; Nishiyama Y.; Kimura H. Quantitative analysis of Epstein-Barr virus(EBV)-related gene expression in patients with chronic active EBV infection, Genvirol,2010, 91(1),42-50. DOI: 10.1099/vir.0.013482-0

38. Yoshiba F.; Hsgham M.; Tmume K.; Ogawa Y.; Kishi K.; Higuchi A.; Kato S.; Hotta T. Complete resolution of severe chronic active Epstein-Barr virus infection by cultured, activated donor $\mathrm{T}$ lymphocyte infusion after nonmyeloablative stem cells allografting, Bone Marrow T ransplant,2003, 32(1),107. DOI: 10.1038/sj.bmt.1704074

39. Savoldo B.; Hhuls A,H,; Liu zhe Z. Autologous Epstein-Barr virus (EBV)specific cytotoxic $\mathrm{T}$ cells for treatment of persistent active EBV infection, Blood, 2002, 100(12),4059-4066. DOI: 10.1182/blood2002-01-0039

40. Okamura T.; Hatsukawa Y.; Arai H.; Inoue M.; Kawa K. Blood stem-cell transplantation for chronic active Epstein-Barr virus with lymphoproliferation, Lancet, 2000, 356(9225), 223-4. DOI: 10.1016/S01406736(00)02488-0

41. Jeffery I.C.; Elaine S.J.; Janet K.D.; Cohen J.I.; Jaffe E.S.; Dale J.K.; Pittaluga S.; Heslop H.E.; Rooney C.M.; Gottschalk S.; Bollard C.M.; Rao V.K.; Marques A.; Burbelo P.D.; Turk S.P.; Fulton R.; Wayne A.S.; Little R.F.; Cairo M.S.; El-Mallawany N.K.; Fowler D.; Sportes C.; Bishop M.R.; Wilson W.; Straus S.E. Characterization and treatment of chronic active Epstein-Barr virus disease: a 28-year expedence in the United States, Blood, 2011, 117(22),58355849. DOI: 10.1182/blood-2010-11-316745

42. Fujii N.; Takenaka K.; Hiraki A.; Maeda Y.; Ikeda K.; Shinagawa K.; Ashiba A.; Munemasa M.; Sunami K.; Hiramatsu Y.; Ishimaru F.; Niiya K.; Yoshino T.; Harada M. Allogeneic peripheral blood stem cell transplantation for the treatment of chronic active Epstein-Barr virus infection, Bone
Marrow Transplant, 2000, 26(7),805-8. DOI: 10.1038/sj.bmt.1702600

43. Kawa K.; Sawada A.; Sato M.; Okamura T.; Sakata N.; Kondo O.; Kimoto T.; Yamada K.; Tokimasa S.; Yasui M.; Inoue M. Excellent outcome of allogeneic hematoietic SCT with reduced intensity conditioning for the treatment of chronic active Epstein-Barr virus infction, Bone Marrow Transplant, 2011, 46(1),77-83. DOI: 10.1038/bmt.2010.122

44. Gotoh K.; Ito Y.; Shibata-watanabe Y.; Kawada J.; Takahashi Y.; Yagasaki H.; Kojima S.; Nishiyama Y.; Kimura $H$. Clinical and virological characteristics of 15 patients with chronic active Epstein-Barr virus infection treated with hematopoietic stem cell transplantation, Clin lnfect Dis, 2008, 46(10), 1525-1534.

45. Iwata S.; Yano S.; Ito Y.; Ushijima Y.; Gotoh K.; Kawada J.; Fujiwara S.; Sugimoto K.; Isobe Y.; Nishiyama Y.; Kimura H. Bortezomib induces apoptosis in $\mathrm{T}$ lymphoma cells and natural killer lymphoma cells independent of Epstein-Barr virus infection, Int J Cancer, 2011, 129(9),226373. DOI: $10.1002 /$ ijc. 25873

46. Iwata S.; Saito T.; Ito Y.; Kamakura M.; Gotoh K.; Kawada J.; Nishiyama Y.; Kimura H. Antitumor activities of valproic acid on Epstein-Barr virus-associated $\mathrm{T}$ and natural killer lymphoma cells, Cancer Sci, 2012, 103(2), 375-81. DOI: 10.1111/j.13497006.2011.02127.x

47. Sullivan JL.; Woda BA.; Herrod HG.; Koh G.; Rivara FP.; Mulder C. Epstein-Barr virus associated hemophagocytic syndrome: virological and immunopathological studies, Blood, 1985,65(5),1097-104.

48. Ishii E.; Ohga S.; Imashuku S.; Kimura N.; Ueda I.; Morimoto A.; Yamamoto K.; Yasukawa M. Review of hemophagocytic lymphohistiocytosis (HLH) in children with focus on Japanese experiences, Critical Reviews in Oncology/Hematology, 2005, 53 (7), 209-223. DOI: 10.1016/j.critrevonc.2004.11.002

49. Janka G.E. Familial and acquired hemophagocytic lymphohistiocytosis, Eur J 
Pediatr, 2007, 166(2),95-109. DOI: 10.1007/s00431-006-0258-1

50. Imashuku S. Clinical features and treatment strategies of Epstein-Barr virus-associated hemophagocytic lymphohistiocytosis, Critic Rev Oncol/Hematol, 2002, 44(14),259-272. DOI: 10.1016/S1040-8428(02)00117-8

51. Kasahara Y.; Yachie A. Cell type specific infection of Epstein-Barr virus (EBV) in EBV-associated hemophagocytic lymphohistiocytosis and chronic active EBV infection, Crit Rev Oncol Hematol, 2002, 44(3), 283-294. DOI: 10.1016/S10408428(02)00119-1

52. Qiang Q.; Zheng-De X.; Chun-Yan L.; KunLing S. Expression of NK cell surface receptors and CD107a in Epstein-Barr virus associated hemophagocytic lymphohistiocytosis children, Chin J Evid Bas Pediatr, 2010, 10(7),136-141.

53. Lee W.I.; Chen S.H.; Hung I.J.; Yang C.P.; Jaing T.H.; Chen C.J.; Li S.P.; Huang J.L. Clinical aspects, immunologic assessment, and genetic analysis in Taiwanese children with hemophagocytic lymphohistiocytosis, Pediatr Infect Dis J, 2009, 28(1), 30-34. DOI: 10.1097/INF.0b013e3181813592

54. Zhizhuo H.; Junmei X.; Yuelin S.; Qiang Q.; Chunyan L.; Zhengde X.; Kunling S. Screening the PRF1, UNC13D, STX11, SH2D1A, XIAP and ITK gene mutations in Chinese children with Epstein-Barr virus associated hemophagocytic lymphohistiocytosis, Pediatr Blood Cancer, 2011, 58(3),410-414. DOI: $10.1002 / \mathrm{pbc} .23216$

55. Henter J.I.; Horne A.; Arico M.; Egeler R.M.; Filipovich A.H.; Imashuku S.; Ladisch S.; McClain K.; Webb D.; Winiarski J.; Janka G. HLH-2004: Diagnostic and therapeutic guidelines for hemophagocytic lymphohistiocytosis, Pediatr Blood Cancer, 2007, 48(2), 124-31. DOI: $\underline{10.1002 / \mathrm{pbc} .21039}$

56. Jin Y.K.; Xie Z.D.; Yang S.; Lu G.; Shen K.L. Epstein-Barr virus associated hemophagocytic lymphohistiocytosis: A retrospective study of 78 pediatric cases in mainland of China, Chin Med J (Engl), 2010, 123(11), 1426-1430.

57. Thompson P.A.; Allen C.E.; Horton T. Severe neurologic side effects in patients being treated for hemophagocytic lyraphohistiocytosis, Pediatr Blood Cancer, 2009, 52(5),621-625. DOI: $10.1002 / \mathrm{pbc} .21838$

58. Henter J.I.; Samuelsson-Horne A.; Aricò M.; Egeler R.M.; Elinder G.; Filipovich A.H.; Gadner H.; Imashuku S.; Komp D.; Ladisch S.; Webb D.; Janka G. Treatment of hemophagocytic lymphohistiocytosis with HLH-94 immunochemotherapy and bone marrow transplantation, Blood, 2002, 100(2),2367-73. DOI: 10.1182/blood-2002$\underline{01-0172}$

59. Ohga S.; Kudo K.; lshii E.; Honjo S.; Morimoto A.; Osugi Y.; Sawada A.; Inoue M.; Tabuchi K.; Suzuki N.; Ishida Y.; Imashuku S.; Kato S.; Hara T. Hematopoietic stem cell transplantation for familial hemophagoeytic iymphohistiocytosis and Epstein-Barr virus associated hemophagocyfic lymphohistiocytosis in Japan, Pextiatr Blood Cancer, 2010, 54(2),299-306. DOI: $10.1002 /$ pbc. 22310

60. Home A.; Janka G.; Maarten Egeler R.; Gadner H.; Imashuku S.; Ladisch S.; Locatelli F.; Montgomery S.M.; Webb D.; Winiarski J.; Filipovich A.H.; Henter J.I. Haematopoietic stem cell transplantation in hanmophagocytic lymphohistiocymsis, BrJ Hacmato1, 2005, 129(5),622-630. DOI: 10.1111/j.1365-2141.2005.05501.x 